\title{
Technology Foresight Analysis Sebagai Metodologi Dalam Pertimbangan Pengembangan Kawasan Cagar Budaya
}

\author{
Karina Pradinie ${ }^{1}$ \\ Rimadewi Suprihardjo ${ }^{2}$ \\ Dian Rahmawati ${ }^{3}$ \\ Rulli Pratiwi Setiawan ${ }^{4}$ \\ ${ }^{1}$ Urban and Regional Planning Department, Institut Teknologi Sepuluh Nopember, Indonesia \\ karina.haricahyono@gmail.com
}

\begin{abstract}
ABSTRAK
Metodologi dalam penelitian kawasan cagar budaya sangat potensial untuk dikembangkan, terutama dalam pendekatan-pendekatan non fisik seperti partisipasi masyarakat. Aspek anthropologi yang dipotret dengan bingkai kajian etnografi, aspek ekonomi dan lingkungan aspek modal budaya dan berlanjutan.

Dalam pengembangan cagar budaya, sangat diperlukan aspek-aspek yang akan mendukung masa depan cagar budaya. Pengetahuan terhadap aspek-aspek tersebut yang dibingkai dalam analisis foresight yang dikembangkan diharapkan bisa menjadi pertimbangan dirumuskan kebijakan-kebijakan yang dapat mendukung pengembangan kawasan cagar budaya ke depan.
\end{abstract}

Keywords: Foresight Analysis, Cagar Budaya, Pengembangan Metode 


\section{PENDAHULUAN}

Pengembangan kawasan cagar budaya dihadapkan pada tantangan - tantangan ketidakpastian dalam masa depan. Ketidakpastian tersebut disebabkan oleh beberapa hal yang meliputi aspek fisik dan aspek non fisik (Supriharjo et al, 2015). Aspek fisik dihadapkan pada beberapa tantangan, yakni: 1). Adaptasi bangunan terhadap fungsi ataupun aktivitas yang semakin modern, 2). Biaya perawatan yang relatif mahal dan terkadang membutuhkan pesanan khusus dalam merenovasi (pewarnaan, dll). Sedangkan aspek non fisik meliputi aspek yang lebih luas lagi, meliputi : 1). Partisipasi masyarakat, 2). Peluang pengembangan cagar budaya di masa mendatang, 3). Nilai - nilai yang melekat dalam cagar budaya tersebut (nilai aestetik, spiritual dan sosio -kultural) (Supriharjo, et, al, 2015), 4) Aspek Antropologi dan 5). Aspek ekonomi (Getty Conservation Institute, 2002). Kedua dimensi tersebut merupakan pondasi dalam mengembangkan kawasan cagar budaya.

Masa depan seringkali dinilai sebagai dimensi yang penuh ketidakpastian, sehingga beberapa peneliti merasa perlu untuk mengembangkan sebuah metodologi dalam memperkirakan masa depan. Perkembangan studi ini dinamakan studi tentang masa depan atau dalam bahasa inggris adalah future studies dan orang orang yang mempelajarinya seringkali disebut sebagai futuris. Beberapa metode dikembangkan baik secara kuantitatif yang seringkali disebut forecasting (ekstrapolasi trend, megatrend dan lain sebagainya) maupun dikembangkan secara kualitatif yang seringkali disebut dengan foresight yang dilakukan dengan menggunakan teknik analisis delphi, brainstorming, technology roadmapping dan lain sebagainya) (UNIDO, 2002).

Dalam pengembangan cagar budaya, sangat diperlukan aspek - aspek yang akan mendukung masa depan cagar budaya.
Pengetahuan terhadap aspek - aspek tersebut, dapat diperkirakan tantangan dan peluang yang mungkin terjadi ke depannya sehingga bisa dirumuskan kebijakan kebijakan yang dapat mendukung pengembangan kawasan cagar budaya ke depan. Pengembangan metodologi foresight dalam cagar budaya menjadi jawaban atas aspek - aspek apa saja yang seharusnya diperhatikan dalam melakukan foresight yang berkaitan dengan cagar budaya ini.

\section{METODE}

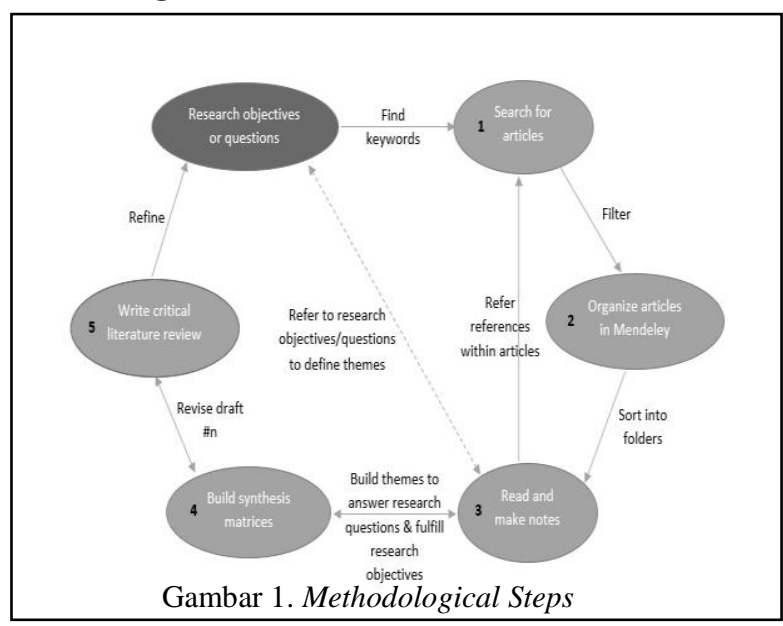

Metodologi yang digunakan dalam menemukan metode foresight ini adalah deduktif kualitatif Dalam ranah penelitian terdapat dua pendekatan besar dalam mendekati obyek penelitiannya yakni induktif yang bergerak dari ranah konret menuju ranah abstrak dan sebaliknya yaitu deduktif yang bergerak dari ranah abstrak menuju konkret (Trochim, 2006).

Untuk mendapatkan sebuah metodologi yang menggabungkan antara studi masa depan (foresight) dan cagar budaya, beberapa langkah yang ditempuh oleh peneliti seperti yang digambarkan dalam gambar 1. Tahap awal adalah memulai dengan mengajukan pertanyaan penelitian yaitu: bagaiamanakah penerapan foresight untuk kawasan cagar budaya yang mempertimbangkan pengembangan pariwisata? Aspek -aspek apa sajakah yang harus diperhatikan?, kemudian 
mengorganisasikan literatur yang digunakan kemudian membuat catatan catatan penting dan membuat matriks sintesa untuk menjawab pertanyaan diatas.

\section{HASIL}

1. Online qualitative exploratory: bertujuan mengeskplorasi driver driver dalam pengembangan wisata cagar budaya dan trend perubahan ke depan. Dalam studi kualitatif, responden dipilih secara purposive sampling dan mengandalkan ekspertise dari responden yang dipilih untuk meningkatkan kredibilitas penelitian. Survey yang dilakukan secara online dan kualitatif digunakan untuk mengeksplorasi tingkat ekpertise dari responden yang akan menjadi panel dalam tahap selanjutnya,

Dalam ranah foresight terdapat 5 faktor pendorong yang menentukan arah kebijakan, meliputi :

a. Sosial : terkait dengan tingkat partisipasi masyarakat dalam mengembangkan kawasan pariwisata budaya dan tingkat penerimaan terhadap wisata cagar

Studi mengenai penggunaan metode foresight yang ditemukan dalam penelitian ini (kajian cagar budaya), memiliki beberapa dimensi ataupun tahapan yang harus diterapkan dalam melakukan peramalan terhadap masa depan meliputi :

budaya;

b. Teknologi: terkait dengan pola penggunaan teknologi dalam kehidupan sehari hari dan juga dalam pariwisata;

c. Ekonomi: terkait dengan peluang ekonomi yang bisa dimanfaatkan dalam mengembangkan wisata cagar budaya dan keuntungan yang

d. Lingkungan: terkait dengan perubahan yang terjadi di kawasan sekitar situs cagar budaya;

e. Politik: terkait perubahan dengan kebijakan dan situasi politik di masa mendatang yang mempengaruhi perubahan cagar budaya.

2. Qualitative exploratory : Responden yang mengisi dari form - form tersebut akan dianalisa dan dikelompokkan menjadi beberapa kategori expert, moderate dan low expertise. Responden yang berada dalam kategori expert akan diundang dalam sebuah panel focus group discussion (FGD) dan mendiskusikan secara terbuka dan mendalam mengenai :

Focal Question: Bagaimana prospek pengembangan cagar budaya sebagai entitas pariwisata di masa mendatang? (bisa difokuskan pada faktor pendorong tertentu sesuai keadaan kawasan cagar budaya masing masing, di bawah hanya merupakan contoh dari faktor pendorong yang dipilih).

- Social driver: persepsi terhadap cagar budaya saat ini, definisi wisata, apa yang diinginkan dalam berwisata, ketertarikan dalam berwisata budaya;

- Technology: bagaimana menggunakan teknologi dalam berwisata? (mencari informasi sampai di tempat tujuan), apa saja teknologi/ app yang digunakan saat ini;

3. Quantitative : Untuk memvalidasi hasil temuan - temuan eksplorasi qualitative. Sampling yang digunakan adalah random sampling dengan Slovin lalu dilakukan uji validitas dan realibilitas. 
Ketiga tahapan tersebut dapat dilihat

dalam ilustrasi dalam Gambar 2 berikut ini.

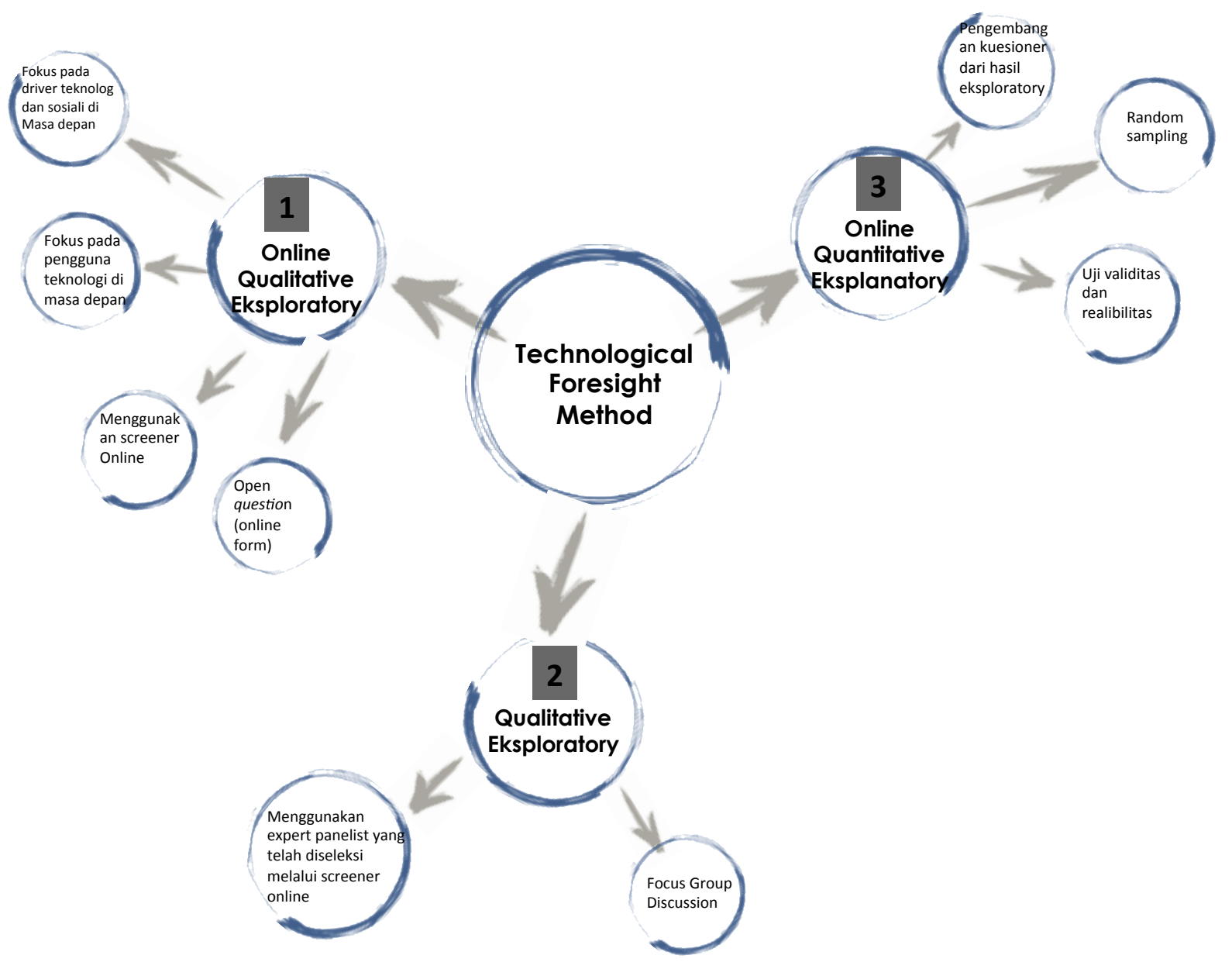

Gambar 2. Technological Foresight For Heritage Process Sumber: Rimadewi, et al, 2016 


\section{Pembahasan}

Foresight dalam dimensi perencanaan bukan sebuah bentuk peramalan yang pasti, namun bagaimana peneliti atau perencana mampu mengantisipasi kejadian - kejadian di masa mendatang dengan memperkirakan semua kemungkinan yang terjadi dalam bentuk skenario atau yang dikenal sebagai scenario planning. Kegunaan metode ini adalah untuk membantu perencana mengenali dimensi masa depan, yang terdiri atas :

1. Dimensi plausible future (probable and preferable). Dimensi ini menggambarkan apa yang dapat atau sangat mungkin terjadi berdasarkan dari trend yang ada baik perhitungan secara kuantitatif ataupun estimasi kualitatif atau yang disebut dengan probable future. Dalam dimensi ini juga terdapat dimensi yang dinamakan preferable future yang merupakan salah satu refleksi dari masa depan yang diinginkan dan dibingkai dalam kerangka rekayasa baik secara teknis maupun kebijakan.

2. Dimensi possible future yaitu merupakan dimensi yang mempertimbangkan semua kemungkinan yang terjadi, termasuk kejadian yang paling ekstrim dan tidak terduga semisal dengan keberadaan bencana ataupun estimasi paling optimis yang sering dinamakan dengan wild card.

Aplikasi skenario planning dalam perencanaan ini mempertimbangkan beberapa tahap yang harus dilalui dimana analisis foresight yang dikembangkan dalam penelitian ini mencakupi beberapa tahapan besarnya, yakni : 
Tabel 1. Posisi Analisa Technology Foresight dalam Kajian Skenario Planning

\begin{tabular}{|c|c|c|}
\hline Tahapan & Implikasi Pada Foresight Cagar Budaya & Dimensi \\
\hline $\begin{array}{l}\text { Identifikasi } \\
\text { pertanyaan fokal }\end{array}$ & $\begin{array}{l}\text { Fokus pada pertanyaan apa yang akan terjadi di kawasan } \\
\text { cagar budaya di masa mendatang, tema cukup luas } \\
\text { semisal: } \\
\text { - apakah pengembangan kawasan cagar budaya } \\
\text { potensial sebagai wisata di masa mendatang? } \\
\text { - apa teknologi yang tepat dalam mempromosikan } \\
\text { wisata cagar budaya mendatang dan lain } \\
\text { sebagainya. }\end{array}$ & \multirow{5}{*}{$\begin{array}{l}\text { Dimensi } \\
\text { analisis } \\
\text { Technology } \\
\text { Foresight }\end{array}$} \\
\hline & $\begin{array}{l}\text { Pada analisis foresight yang dirumuskan, pertanyaan ini } \\
\text { dieksplorasi melalui tiga tahapan seperti yang dijelaskan } \\
\text { dalam gambar } 2 \text {. }\end{array}$ & \\
\hline \multirow[t]{2}{*}{$\begin{array}{l}\text { Environmental } \\
\text { Scanning }\end{array}$} & $\begin{array}{l}\text { Fokus untuk menjawab keadaan eksisting yang kemudian } \\
\text { menggambarkan apa potensi, masalah, peluang dan } \\
\text { tantangan pertanyaan fokal yang telah disebutkan di } \\
\text { masa mendatang. }\end{array}$ & \\
\hline & $\begin{array}{l}\text { Lingkungan yang dimaksud meliputi lingkungan secara } \\
\text { fisik, ekonomi, sosial dan budaya. }\end{array}$ & \\
\hline $\begin{array}{l}\text { Memilih faktor } \\
\text { pendorong perubahan }\end{array}$ & $\begin{array}{l}\text { Faktor pendorong dapat dipilih dari } 5 \text { faktor yang telah } \\
\text { dijelaskan meliputi: } \\
\text { a. Sosial : terkait dengan tingkat partisipasi masyarakat } \\
\text { dalam mengembangkan kawasan pariwisata budaya } \\
\text { dan tingkat penerimaan terhadap wisata cagar } \\
\text { budaya; } \\
\text { b. Teknologi: terkait dengan pola penggunaan } \\
\text { teknologi dalam kehidupan sehari -hari dan juga } \\
\text { dalam pariwisata; } \\
\text { c. Ekonomi: terkait dengan peluang ekonomi yang bisa } \\
\text { dimanfaatkan dalam mengembangkan wisata cagar } \\
\text { budaya dan keuntungan yang } \\
\text { d. Lingkungan: terkait dengan perubahan yang terjadi } \\
\text { di kawasan sekitar situs cagar budaya; } \\
\text { e. Politik: terkait perubahan dengan kebijakan dan } \\
\text { situasi politik di masa mendatang yang } \\
\text { mempengaruhi perubahan cagar budaya }\end{array}$ & \\
\hline $\begin{array}{l}\text { Membangun matriks } \\
\text { skenario }\end{array}$ & & \multirow{3}{*}{$\begin{array}{l}\text { Dimensi } \\
\text { skenario } \\
\text { planning }\end{array}$} \\
\hline $\begin{array}{l}\text { Mengembangkan } \\
\text { skenario }\end{array}$ & & \\
\hline $\begin{array}{l}\text { Mempertimbangkan } \\
\text { implikasi dari skenario }\end{array}$ & & \\
\hline
\end{tabular}

Sumber: Sumber: Rimadewi, et al, 2016

\section{KESIMPULAN}

Pengembangan metodologi ini mengacu pada prinsip validitas dan realibilitas tertinggi karena menggunakan dua metode dalam satu penelitian yakni kuantitatif dan kualitatif, sehingga dalam perencanaan berbasis skenario, hasil - hasil yang didapatkan dapat diaplikasikan sesuai dengan antisipasi pada kejadian - kejadian mendatang. Tentunya dengan ketidaksempurnaan yang ada model ini memiliki beberapa keuntungan yakni menyingkat pencarian expert yang 
diinginkan dengan menggunakan sarana teknologi internet dan mendapatkan wawasan baru sebagai feedback kuesioner kuantitatif yang akan dijadikan acuan untuk memprediksikan pola di masa mendatang. Di sisi yang lain kelemahan metode ini adalah membutuhkan waktu yang lebih lama untuk hasil yang lebih baik, harus dijalankan oleh fasilitator yang handal, hasil yang didapatkan sangat bergantung dengan screening responden untuk mendapatkan hasil yang paling baik dan terutama adalah tidak semua memiliki pengetahuan terhadap teknologi yang setara.

\section{DAFTAR RUJUKAN}

Getty Conservation Institute (2002). Assessing The Value of Cultural Heritage, ed. Marta de la Torre. Los Angeles: Getty Conservation Institute.

Supriharjo, Rimadewi, Pradinie, Karina, Setiawan, Rulli P, Rahmawati, Dian \& Budi Santoso, Eko (2015). The Preservation Of Kemasan Kampong Heritage Area, LPPM ITS.

Supriharjo, Rimadewi, Pradinie, Karina, Setiawan, Rulli P, Rahmawati, Dian \& Budi Santoso, Eko (2015). The Preservation Of Kemasan Kampong Heritage Area, (Community Participation) LPPM ITS.

Pradinie, Karina, et. All (2015). The RAFHAM. Unpublished.

Trochim, William M. The Research Methods Knowledge Base, 2nd Edition. Internet WWW page, at URL: $<$ http://www.socialresearchmethods.net/kb /> (version current as of October 20, 2006). 